\title{
Amending Insurrection: Restoring the Balance of Power in The Insurrection Act
}

Jeremy S Campbell

Texas A\&M University School of Law (Student), campbjer@tamu.edu

Follow this and additional works at: https://scholarship.law.tamu.edu/lawreview

Part of the Military, War, and Peace Commons, National Security Law Commons, and the President/ Executive Department Commons

\section{Recommended Citation}

Jeremy S Campbell, Amending Insurrection: Restoring the Balance of Power in The Insurrection Act, 9 Tex. A\&M L. Rev. 239 (2021).

Available at: https://doi.org/10.37419/LR.V9.I1.6

This Comment is brought to you for free and open access by Texas A\&M Law Scholarship. It has been accepted for inclusion in Texas A\&M Law Review by an authorized editor of Texas A\&M Law Scholarship. For more information, please contact aretteen@law.tamu.edu. 


\title{
AMENDING INSURRECTION: RESTORING THE BALANCE OF POWER IN THE INSURRECTION ACT
}

\author{
by: Jeremy Campbell*
}

\begin{abstract}
The Insurrection Act allows the president to domestically deploy and utilize the federal standing army and state militias to perform functions normally performed by domestic law enforcement. The president can invoke the Act when circumstances make it impracticable to enforce domestic law by normal means, when the execution of the law is obstructed such that it deprives citizens of rightful legal protections, or upon the request of a state. Under the current version of the Act, the president possesses the sole and absolute discretion to determine when it is invoked during the two former instances above. When invoked, the Act provides broad and largely undefined authority for the president to act. This Comment reviews the history behind the passage of the Insurrection Act and follows the subsequent amendments to the contemporary version. It argues that Congress and the Supreme Court have failed to provide adequate checks on the president's domestic military power, to determine the source of this power, and to accurately describe the limits of the president's power under the Act. By failing to adhere to the conception of military involvement in domestic law enforcement that the Founders envisioned, the nation is left vulnerable to serious abuses of power for the sake of expediency. This Comment shows that restoring checks on the president's power under the Insurrection Act will eliminate the possibility of presidential abuse without reducing the usefulness of the Act.
\end{abstract}

TABle of Contents

I. Introduction................................ 240

II. The Insurrection Act........................ 244

A. Early Influences on Domestic Presidential Military Power....................................... 244

B. The Militia Acts........................... 246

C. The Insurrection Act of $1807 \ldots \ldots \ldots \ldots \ldots \ldots . . .247$

D. Amendments to the Insurrection Act ............ 249

E. The Modern Insurrection Act ................ 251

III. Use in Modern Times .......................... 252

A. Little Rock, Arkansas, 1957 .................. 252

B. Alabama 1963 and the Stand in the Schoolhouse Door...................................... 254

C. Rodney King Riots 1992 ..................... 256

IV. Amending Insurrection ....................... 257

A. The Language at Issue ....................... 257

DOI: https://doi.org/10.37419/LR.V9.I1.6

* J.D. Candidate, Texas A\&M University School of Law, May 2022. I would like to thank my advisor, Professor John F. Murphy, for helping to organize, structure, and develop my ideas. I would like to especially thank my wife, Emma Campbell, for her invaluable support throughout the writing process and law school as a whole. 
B. Recently Proposed Amendments ............... 258

C. Obtaining Approval and Other Checks........... 260

1. Process for Obtaining Independent

Certification ............................. 260

2. Time Limits for Presidential Action .......... 262

3. Additional Checks ....................... 263

D. Restoring the Balance ....................... 264

E. The Posse Comitatus Act ..................... 265

V. Conclusion ............................... 266

\section{INTRODUCTION}

Protesters flood the streets of major American cities. The demonstrators, enraged by discriminatory policies and fueled by a pervasive sense of political injustice, overwhelm entire city blocks. Some of these demonstrations are peaceful, but others will be remembered for their indiscriminate violence and destruction. Businesses are burned and looted by violent protestors, and peaceful and violent protestors alike are tear-gassed and beaten by law enforcement. The aftermath reveals a divided nation. The nation's citizens look to their elected leaders; they demand that their representatives take action. The demands range from suppressing the protests-peaceful ones includedto listening to the protestors' pleas and fighting for justice on their behalf. The only point of agreement between the nation's divided sides is that something must be done. The president, dissatisfied with the affected states' responses, unilaterally deploys federalized military forces to suppress the demonstrations across the nation and restore one side's conception of "law and order." Despite pushback from governors, state legislatures, and the nation's citizens, the president commands the troops to remain where they are until he determines the insurrection is suppressed. In this way, the federal military becomes an agent of domestic law enforcement against the will of the states and their citizens.

This scenario is not unique in American history. ${ }^{1}$ The hypothetical above is not truly hypothetical, not even the part about deploying federalized troops. ${ }^{2}$ In fact, it falls short of the worst case scenario because it omits the suspension of habeas corpus and the declaration of martial law, which under the circumstances described is a possibility. ${ }^{3}$ Acting with authority granted by the Insurrection Act, the president has unilaterally federalized and deployed military forces to enforce

1. See Jonathon Berlin \& Kori Rumore, 12 Times the President Called in the Military Domestically, CHI. TriB. (June 1, 2020, 5:49 PM), https://www.chicagotribune. $\mathrm{com} /$ news/ct-national-guard-deployments-timeline-htmlstory.html [https://perma.cc/ 2X4E-36M9].

2. $I d$.

3. Stephen I. Vladeck, Emergency Power and the Militia Acts, 114 YALE L.J. 149, 168-69 (2004). 
federal law on multiple occasions throughout our nation's history. ${ }^{4}$ In light of the 2020 protests and the response to those events, it is unsurprising that racial tensions are often the root cause behind these deployments. ${ }^{5}$ The Act, in part, provided the legal basis for fighting the Civil War and was used to enforce the desegregation of schools. ${ }^{6}$ Admittedly, the broad powers the Act bestows upon the president have been exercised responsibly and in ways that most people could agree were for the greater good. ${ }^{7}$ However, this Comment argues that the Act, even when used responsibly, bestows too much power upon a single individual; therefore, that power should be restricted. This is particularly true when the restrictions will not impede the Act's usefulness to suppress insurrections.

Recently, the May 25, 2020 death of George Floyd, a Black man who died in police custody, renewed the people's outrage regarding police treatment of Black Americans and caused protests and demonstrations to erupt across the nation. ${ }^{8}$ The rhetoric of members of Congress, political pundits, and even President Donald Trump suggested that some of these protests rose to the level of insurrection. ${ }^{9}$ In response, the president proposed that he would use the military to quickly quell the protests by invoking the Insurrection Act. ${ }^{10}$ The suggestion raised questions for many Americans, including whether the president has the power to deploy military forces into states that have not requested them, where the authority to deploy troops domestically is derived from, and what are the limits to this power.

Due to the circumstances of our nation's founding and the experiences of the Framers, domestic deployment of military forces has been controversial throughout American history and will likely remain that way. ${ }^{11}$ The Framers experienced firsthand the tyranny that can result from an improper distribution of military power, and this is reflected in the way they originally delegated control of the standing army and the state militias. ${ }^{12}$ It is easy to dismiss the fears early Americans had concerning a centrally commanded, federal standing army as

4. Berlin \& Rumore, supra note 1.

5. See id.

6. Id.; Dave Roos, Thomas Jefferson Signed the Insurrection Act in 1807 to Foil a Plot by Aaron Burr, Hist. (June 3, 2020), https://www.history.com/news/insurrectionact-thomas-jefferson-aaron-burr [https://perma.cc/9N89-ZLK8].

7. See Berlin \& Rumore, supra note 1.

8. Andrew Craft, Insurrection Act Debate Rages on in Congress over Use of Military Force to Quell Protests, Fox News (June 5, 2020), https://www.foxnews.com/politics/insurrection-act-debate-rages-on-over-use-of-military-force-to-quell-protests [https://perma.cc/G5E5-P94Q].

9. See id.

10. Madeleine Carlisle, What Is the Insurrection Act and Does It Give Trump the Authority to Send Military Troops into States? Here's What to Know, Time (June 2, 2020, 4:10 PM), https://time.com/5846649/insurrection-act-1807-donald-trump/ [https:/ /perma.cc/6A65-6TM9].

11. Vladeck, supra note 3 , at 157.

12. $I d$. 
irrelevant to contemporary society, but it is important to keep in mind that these fears existed even when the militias of the several states were largely disorganized and the standing army was nearly nonexistent. ${ }^{13}$ Presumably, the Framers would be astonished to learn the modern American standing army is among the largest in the world with a budget that exceeded the combined budget of the next seven countries on a 2018 list. ${ }^{14}$ The thought of a president using the military to unilaterally enforce a political agenda is shocking, but the capability and resources are present. Citizens of a democracy should always be concerned about improper distributions of power especially when the power at issue is militaristic and when lawmakers continually move away from the balance of power the Founders intended. ${ }^{15}$

Despite the experiences of our nation's Founders, the sources and extent of the executive branch's military power to respond to a crisis or insurrection within the United States is far from being sharply defined. ${ }^{16}$ The positions scholars take on the source of domestic presidential military power vary widely; some argue the president only possesses the powers the Constitution and Congress explicitly delegated to the executive branch, while others argue the president has the powers just mentioned and unwritten powers that are inherently granted by the Constitution. ${ }^{17}$ The conception of emergency power, which appears to most accurately reflect the way the executive operates, suggests that the president wields both the powers that the Constitution and Congress explicitly delegated to the executive branch plus extraconstitutional powers (powers not listed in the Constitution) due to the unique duties the Constitution imposes upon the president. ${ }^{18}$ The extent of the president's power to act once troops are deployed during a crisis is even less clear. Throughout the nation's history, the Supreme Court has, though rarely, provided guidance and murky limitations on the president's ability to act when exercising emergency domestic military power. ${ }^{19}$ Instead, the Constitution, Congress, and history have directed the Act's use.

Importantly, Article I of the Constitution grants Congress the power " $\mathrm{t}$ ]o provide for calling forth the Militia to execute the Laws of the Union, suppress Insurrections and repel Invasions." ${ }^{20}$ Some schol-

13. Id. at $163-64$.

14. Robert Artiga-Valencia, The U.S. Spends More on Its Military than 144 Countries Combined, Nat'L Priorities Project (July 18, 2019), https:// www.nationalpriorities.org/blog/2019/07/18/us-spends-more-its-military-176-countriescombined/ [https://perma.cc/LAR3-J7A4].

15. See Vladeck, supra note 3 , at 169.

16. Candidus Dougherty, "Necessity Hath No Law": Executive Power and the Posse Comitatus Act, 31 Campbell L. Rev. 1, 11, 17 (2008).

17. Id. at $18-19$.

18. Id. at $22-23$.

19. See id. at 42; Vladeck, supra note 3 , at 169-80.

20. U.S. Const. art. I, § 8, cl. 15. 
ars refer to this clause as the "First Militia Clause." 21 Congress eventually delegated the "calling-forth" powers created by the First Militia Clause to the executive branch. ${ }^{22}$ The history of the delegation and the evolution of the powers that came with it is discussed in Part II. For now, it is sufficient to understand that the Constitution did not originally vest the calling-forth power in the executive branch. Congress, not the Constitution, granted the president the powers the office currently possesses. ${ }^{23}$

The Insurrection Act was originally passed in 1807; however, the Militia Acts preceded it and functioned similarly. ${ }^{24}$ The Insurrection Act is of particular interest not only because it grants the president sole discretion of when to invoke the $\mathrm{Act}^{25}$ but also because the power to suspend habeas corpus and impose martial law accompanies the powers the Act granted to the president under certain circumstances-circumstances about which the Supreme Court has only provided limited guidance. ${ }^{26}$ Even more concerning, some Supreme Court decisions suggest the president's determination of whether a situation is an insurrection is largely unreviewable by the courts. ${ }^{27}$

Over time, Congress has consistently reduced the checks on the president's powers under the Act. ${ }^{28}$ Congress could restore those checks by amending the unilateral language of $\S 252$ and $\S 253$ of the Insurrection Act. Until checks are once again placed on presidential power, the possibility that a president will abuse this power will persist. At a minimum, Congress should outline the limits of presidential power under the Act or provide guidance about the degree of power that can be exercised in specific situations. The mere possibility of abuse alone should motivate Congress to place checks on the president's domestic military powers when the executive branch is unlikely to willingly submit to additional restrictions.

Part II of this Comment describes the historical events and laws leading to the Insurrection Act's enactment in 1807. This Part details the passage of the Militia Acts, their influence on the Insurrection Act of 1807, and the subsequent amendments to the Insurrection Act up to the modern-day version. Part III discusses and analyzes select instances of the Insurrection Act's usage in modern times. Part IV begins with a discussion of recent congressional proposals to limit presidential power under the Insurrection Act. This Part critiques those proposals and proposes additional mechanisms to obtain congressional approval or judicial certification. Further, it considers limi-

21. Vladeck, supra note 3, at 152-53.

22. $I d$.

23. But see Dougherty, supra note 16 , at 17-18.

24. Vladeck, supra note 3, at 163-64.

25. Id. at 164,168 .

26. Id. at $168-69$.

27. Id. at $171-73$.

28. Id. at 169. 
tations the president must adhere to before and during the exercise of domestic military powers. Lastly, Part IV briefly explains the relevance of the Posse Comitatus Act, a criminal statute, to the Insurrection Act insofar as the Posse Comitatus Act can be used to restrict presidential power. Finally, Part V concludes that Congress should amend $\S 252$ and $\S 253$ of the Insurrection Act to require the president to obtain some form of congressional approval or judicial certification prior to deploying federalized troops when a state has not requested them.

\section{The Insurrection Act}

To fully appreciate the disparity between the largely unchecked powers delegated to the president under the modern Insurrection Act and the Framers' original conception of the president's domestic military powers, it is necessary to review the congressional acts responsible for the delegation and evolution of these powers. This analysis begins by explaining the attitudes the Framers held toward military involvement in domestic affairs, the issues debated at the Philadelphia Convention, and how they both influenced early formulations of presidential military power. Next, the focus shifts to the Militia Acts, starting with the first temporary congressional delegation of the First Militia Clause's powers to the president and ending with the modern version of the Act. The powers delegated in the Militia Acts do not constitute the entirety of the emergency powers statutorily delegated to the president; there are many others. But the Militia Acts and the subsequent Insurrection Act represent Congress's explicit delegation of very serious military power with surprisingly limited checks. ${ }^{29}$

\section{A. Early Influences on Domestic Presidential Military Power}

Historically, when a professional standing army enforced domestic law, the outcome was largely negative. ${ }^{30}$ Our nation's Founders learned this through experience; they fought the Revolutionary War to escape it. ${ }^{31}$ The Boston Massacre in 1770, when British soldiers sent to enforce tax collection laws killed five colonists, ${ }^{32}$ was only one example of the tyranny that using a standing army to enforce domestic law could cause. The Founders were afraid of escaping from military domination only to create another powerful standing army that would dominate them again and defeat the purpose of forming a new nation. ${ }^{33}$ This fear was apparent in the Articles of Confederation, which required the states to maintain their militias but forbade them from

29. Id. at $153-54$.

30. Dougherty, supra note 16 , at 1.

31. Id. at 5-6.

32. Jeff Wallenfeldt, Boston Massacre, EncYC. BRITANnICA, https:// www.britannica.com/event/Boston-Massacre [https://perma.cc/PE67-GLUL].

33. Vladeck, supra note 3, at 156. 
raising armies or navies in times of peace. ${ }^{34}$ One of the problems with the Articles of Confederation was that the federal government could not force the states to cooperate with its requests for troops. ${ }^{35}$ Essentially, the fear of a powerful centralized army influenced the authors of the Articles of Confederation to create an every-state-for-themselves military system. ${ }^{36}$

To better understand the context of the Articles of Confederation, it is useful to know that the Constitution makes the distinction between the "militia" (now known as the National Guard) and the Army and Navy (the "standing army") of the United States that is referred to in the Commander in Chief Clause. ${ }^{37}$ The military system of the early United States was drastically different from the integrated and massive military we are familiar with today. Originally, the militias of each state, consisting of "citizen-soldiers," were the nation's primary military instrument because of the desire to avoid a powerful standing army. ${ }^{38}$

By the time the Founders met at the Philadelphia Convention in $1787,{ }^{39}$ the fear of a centrally commanded standing army had not dissipated, but the Founders understood that the current system under the Articles of Confederation was unworkable. ${ }^{40}$ The debate at the Philadelphia Convention was less about whether there should be a standing army and more about who would have the power to call forth this army. ${ }^{41}$ An important consequence of that debate is the separation of powers between the three branches of government we have today. ${ }^{42}$

When Congress first ratified the Constitution, the Commander in Chief Clause granted the president the authority to command the standing army ${ }^{43}$ raised by Congress ${ }^{44}$ and the militias of the several states, but the president could only command the militias when the they were "called into the actual Service of the United States." 45 Originally, only Congress could call the militias of the several states into actual service. ${ }^{46}$ As mentioned earlier, Article I of the Constitution (or the First Militia Clause) exclusively grants Congress the power

34. Dougherty, supra note 16 , at 6 .

35. Vladeck, supra note 3, at 156-57.

36. See id. at 157.

37. U.S. Const. art. II, § 2, cl. 1 .

38. Alan Hirsch, The Militia Clauses of the Constitution and the National Guard, 56 U. Cin. L. Rev. 919, 924, 936 (1988).

39. Constitutional Convention Begins, Hist., https://www.history.com/this-day-inhistory/constitutional-convention-begins (May 21, 2020) [https://perma.cc/2CJQ5FK8].

40. Vladeck, supra note 3, at 157.

41. Dougherty, supra note 16 , at 6.

42. See id.

43. U.S. Const. art. II, § 2, cl. 1.

44. Id. art. I, § 8, cl. 12 .

45. Id. art. II, $\$ 2$, cl. 1 .

46. Id. art. I, \& 8, cl. 15 . 
"[t]o provide for calling forth the Militia to execute the Laws of the Union, suppress Insurrections and repel Invasions." 47 Interestingly, the Constitution did not grant either the president or Congress express authority to use the standing army in domestic affairs. ${ }^{48}$

\section{B. The Militia Acts}

In 1792, the Second Congress temporarily delegated the power to call forth the militia and perform the duties prescribed within the First Militia Clause - to execute the laws of the union, suppress insurrections, and repel invasions - to the president with several checks on the power. ${ }^{49}$ The 1792 Calling Forth Act granted the president the authority to "call forth" the militias of the several states to perform the three functions set out in the First Militia Clause. ${ }^{50}$ Additionally, for domestic insurrections, the president could not deploy the militias into a state without a request from the state's legislature or executive. ${ }^{51}$ Even further, the president only had a limited time to act and was required to issue a proclamation to disperse prior to troop deployment and obtain authorization from a federal judge. ${ }^{52}$ The delegation of the calling-forth power was intended to only last three years and function as an experimental delegation of power. ${ }^{53}$ Within two years, President George Washington invoked the 1792 Calling Forth Act to suppress the Whiskey Rebellion. ${ }^{54}$ The success of that experiment ultimately led Congress to permanently delegate an expanded version of the calling-forth power to the president with the 1795 Militia Act despite Washington's criticisms. ${ }^{55}$

The 1795 Militia Act removed several of the checks on the president's power. ${ }^{56}$ Under the 1795 Act, the president was not required to obtain authorization from a federal judge, which meant the president exercised sole authority to decide if a situation warranted deployment of the militias. ${ }^{57}$ Additionally, the proclamation to disperse requirement was kept, but the 1795 Act could be interpreted to allow the president to simultaneously issue the proclamation and deploy troops. ${ }^{58}$ Originally, with the 1792 Act, the president had to issue the proclamation to disperse, and only when the proclamation was ig-

47. Id.

48. Vladeck, supra note 3, at 157-58.

49. Id. at 159-60.

50. Dougherty, supra note 16 , at 9-10.

51. Id.

52. Id.

53. Vladeck, supra note 3 , at 160.

54. Id.

55. Id. at 161-62.

56. Id. at 162 .

57. Id.

58. Id. 
nored could the president deploy the militias. ${ }^{59}$ The 1795 Act expedited the process, which allowed the president to act much quicker. It is worth considering, however, that it was the success of the 1792 Militia Act experiment that presumably made Congress more comfortable delegating expanded powers to the president. ${ }^{60}$ The experiment's success should be a testament to the idea that the president can effectively wield domestic military powers even when it is a multi-step process.

Congress expanded the president's power again in 1799, temporarily authorizing the use of the standing federal army-separate from the militias of the several states-when the 1795 Act would have authorized the use of the militias. ${ }^{61}$ Prior to 1799 , the president could only call forth the state militias to address domestic problems, so this was a significant departure from the 1792 and 1795 Militia Acts. ${ }^{62}$ For the first time, the president could use the standing federal army in domestic affairs. ${ }^{63}$

In summary, by 1799 the president could unilaterally determine if a domestic situation warranted deployment of federalized troops. Those troops could be either militiamen from the several states or federal troops from the standing army (temporarily in 1799). The troops could be deployed simultaneously with the proclamation to disperse.

\section{The Insurrection Act of 1807}

The next expansion of the president's domestic military powers occurred in 1807 with the passage of the Insurrection Act. ${ }^{64}$ The Ninth Congress permanently delegated the power to use both federal forces and state militias when the Act is invoked and it is lawful for the state militias to be called forth. ${ }^{65}$ The Insurrection Act of 1807 is simply the 1795 Militia Act with one sentence added, which is only a slight variation of the 1799 amendment. ${ }^{66}$ Curiously, unlike the 1799 temporary amendment, Congress omitted the language that granted the president authority to use federal forces to repel invasions when the militias could also be used. ${ }^{67}$ Unfortunately, Congress's reasoning can only be guessed at because despite Congress delegating serious military power to the president, there is no legislative history associated with the Insurrection Act of $1807 .{ }^{68}$ Instead, history suggests the Act was signed into law to respond to the threat of Spanish troops at the

59. Id. at 163.

60. See id. at 161-62.

61. Id. at 164 .

62. Id. at 163 .

63. Id. at 164 .

64. Id.

65. Id.

66. See id.

67. See id.

68. Id. 
southern border and to foil Aaron Burr's attempt to raise an army and claim southern territory. ${ }^{69}$

In 1804, Burr shot and killed his political rival, Alexander Hamilton, in a duel. ${ }^{70}$ Burr, who had served as Thomas Jefferson's vice president, was politically ruined. ${ }^{71}$ Burr's extravagant political ambitions did not fade, and although the details of the plan are not clear, Burr supposedly plotted with General James Wilkenson to raise an army and start a war with Spain. ${ }^{72}$ Once news of the plan leaked, Wilkenson, the first governor of the Louisiana Territory, wrote a letter to Thomas Jefferson that revealed the plan without naming Burr. ${ }^{73}$ Jefferson did not need to be told who the co-conspirator was; he already suspected Burr. ${ }^{74}$ This prompted Jefferson to write a letter to James Madison, the then-Secretary of State, asking if the Constitution permitted him to deploy the federal standing army to foil Burr's plot. ${ }^{75}$ Madison, strictly interpreting the Constitution, replied that the Constitution did not allow for federal troops to be used to capture Burr. ${ }^{76}$ After receiving Madison's response, Jefferson did not deploy the federal standing army and requested that Congress enact a bill "authorising the emploiment of the land or Naval forces of the US[] in cases of insurrection."77 Months later, on March 3, 1807, the Insurrection Act became law and, Aaron Burr had been in custody for eleven days. ${ }^{78}$

The Insurrection Act of 1807 marked "Congress's departure from the First Militia Clause as the exclusive source of its authority to regulate the President's emergency military power." 79 There are two important points here. The first is that early in the nation's history, Congress and the president viewed the First Militia Clause as the source of the president's emergency domestic military powers. This is evidenced by Thomas Jefferson's refusal to deploy the federal standing army to capture Burr even when there was evidence that Burr intended to claim American territory for himself and the Militia Acts arguably already gave Jefferson authority to act. The second is that Congress exercised broad constitutional authority when it passed the Act, and the subsequent amendments to the Act followed the same trend. ${ }^{80}$ The First Militia Clause did not discuss the use of the federal standing army. ${ }^{81}$ This is important to understand because Congress

69. Roos, supra note 6.

70. Id.

71. $I d$.

72. $I d$.

73. Id.

74. Id.

75. Id.

76. Id.

77. Id.

78. Id.

79. Vladeck, supra note 3 , at 165.

80. Id. at 165-66.

81. Id. at 165 . 
began delegating emergency military powers to the president by drawing broadly on the powers the Constitution granted to it. ${ }^{82}$ The powers that Congress delegated were outside the powers contained in the First Militia Clause. ${ }^{83}$

\section{Amendments to the Insurrection Act}

For fifty-four years, the Insurrection Act remained the same. ${ }^{84} \mathrm{By}$ the time the Act was amended in 1861 to provide the legal basis for waging the Civil War, ${ }^{85}$ the Supreme Court had made two landmark rulings on the scope of the president's authority under the Insurrection Act. ${ }^{86}$ These rulings provide context for the subsequent amendments. The first case is Martin v. Mott, and the second is Luther v. Borden. ${ }^{87}$ In Mott, the Court considered who should have the power to determine when circumstances warranted calling forth the militia. ${ }^{88}$ The Court held that the president alone possesses the authority to determine when the militia should be called forth and that the "law does not provide for any appeal from the judgment of the President." ${ }^{89}$ In Luther, the Court adopted a similar holding but included a line of reasoning no court before or after it has ever ventured into: The power to impose martial law is necessarily included in the powers Congress delegated to the president in the 1795 Militia Act. ${ }^{90}$ No other court has ever pinpointed the source of the president's power to impose martial law in either the Constitution or an act of Congress (that is not temporary)..$^{91}$

Following the reasoning in Mott, the Court ruled that the power to impose martial law "could not be subjected to review by the courts." 92 However, the Luther Court also suggested that if the president should abuse this power, it would be up to Congress to provide the remedy. ${ }^{93}$ The Supreme Court's rulings solidified the absolute discretion the president possesses to determine whether circumstances necessitate calling forth the militia. Additionally, and more interestingly, the Court suggested that Congress delegated the power to impose martial law to the president when the Constitution did not grant Congress that power, nor did Congress enact any statute that created such

82. Id. at $165-66$.

83. Id.

84. Id. at 166.

85. $I d$.

86. Id. at 170 .

87. Martin v. Mott, 25 U.S. 19 (1827); Luther v. Borden, 48 U.S. 1 (1849); Vladeck, supra note 3 , at 170 .

88. Vladeck, supra note 3, at 171.

89. Id. at 172 .

90. Id. at $172-73$.

91. Id. at 173 .

92. Id.

93. Id. 
power. ${ }^{94}$ This ruling appears paradoxical on its face, and from the perspective of the early strict constitutional government, it is. As discussed earlier, the trend has been for Congress to exercise broad and sweeping authority when it delegates emergency powers to the president. The more time that passes, the more powers the president seems to possess-powers that even the Supreme Court has struggled to define. ${ }^{95}$

The third major revision to the Insurrection Act occurred in 1861, which granted the president the legal basis to wage war against the southern states. ${ }^{96}$ The passage of the Suppression of the Rebellion Act of 1861 (an amendment to the Insurrection Act) created a new "triggering event" that the president could use to justify the deployment of federal troops. ${ }^{97}$ In the event of a "rebellion against the authority of the Government of the United States," the president became able to call forth the militias of the several states and the federal standing army to execute the law. ${ }^{98}$ Additionally, the statute included language that expressly granted the president sole discretion to determine when circumstances made it "impracticable" to execute the law thus triggering the Act. ${ }^{99}$ With the 1861 Act in place, the president possessed enormously expanded powers compared to the original 1792 Militia Act. Nearly all the checks included in the 1792 Act were "heavily diluted." 100

The Suppression of the Rebellion Act of 1861 is the last revision to withstand the test of time. Congress enacted the $1871 \mathrm{Ku}$ Klux Klan Act to respond to the southern states' resistance during the Reconstruction, more specifically the Ku Klux Klan and their violent ideologies. ${ }^{101}$ The 1871 Act authorized the president to impose martial law when it was necessary to protect the civil rights conferred by the Fourteenth Amendment. ${ }^{102}$ The 1871 Act resulted in thousands of arrests but was ultimately declared unconstitutional by the Supreme Court in $1882 .{ }^{103}$ This left only the "equal protection of the law" guarantee, or "triggering event," remaining.

Lastly, the Enforcement Act of 2007 was drafted to address the botched response by the federal government to Hurricane Katrina and allow federal troops to assist civilian law enforcement during nat-

\footnotetext{
94. See id. at $172-73$.

95. See id. at $172-75$.

96. Id. at 167.

97. Dougherty, supra note 16 , at 12 .

98. Act of July 29, 1861, ch. 25, § 1, 12 Stat. 281, 281.

99. Id.; Vladeck, supra note 3 , at 167.

100. Vladeck, supra note 3, at 167.

101. Ku Klux Act Passed by Congress, Hist., https://www.history.com/this-day-inhistory/ku-klux-act-passed-by-congress (Apr. 16, 2020) [https://perma.cc/46K7-

102. Vladeck, supra note 3, at 167.

103. Ku Klux Act Passed by Congress, supra note 101.
} XWAR]. 
ural disasters. ${ }^{104}$ The 2007 Act was quietly included in the Defense Authorization Act of 2007-so quietly many lawmakers did not realize they were voting to amend the Insurrection Act, which some scholars believe was a significant factor in the Defense Authorization Act's repeal just a year later in 2008. ${ }^{105}$ Another factor may have been that the 2007 Act bestowed "unprecedented unilateral authority" upon the president to deploy federal and state forces domestically. ${ }^{106}$

\section{E. The Modern Insurrection Act}

The Insurrection Act, in its current form, comprises five statutes codified at 10 U.S.C. $\S 251$ through $\S 255 .{ }^{107}$ The Act grants the president several powers. ${ }^{108}$ Section 251 of the Act authorizes a state's legislature or its governor-if the legislature cannot convene-to request that the president federalize the state's militia and utilize any other armed forces in the number requested by the state. ${ }^{109}$ However, in stark contrast, $\S 252$ and $\S 253$ allow the president to unilaterally federalize a state's militia and federal forces to enforce the nation's laws when circumstances arise that "make it impracticable to enforce the laws of the United States in any State by the ordinary course of judicial proceedings" or that deprive citizens of the equal protection of law guaranteed by the Constitution. ${ }^{110}$ If the president considers it necessary to use military forces in any of these situations, the president is required to issue a proclamation to disperse and provide the insurgents a limited time to cease their activities. ${ }^{111}$ While this is perhaps not the only way the president can deploy federal forces domestically, ${ }^{112}$ the Act provides broad and explicit congressional authority to do so under certain conditions based on the president's discretion. ${ }^{113}$ In fewer words, if troops are not requested by a state, the president alone has the authority to determine and define "insurrection" and to take action based on that unilateral determination with few constraints. ${ }^{114}$

The Insurrection Act in force today is the result of congressional amendments and court rulings that have consistently reduced the checks on the president's power under the Act. ${ }^{115}$ As discussed above,

104. Thaddeus Hoffmeister, An Insurrection Act for the Twenty-First Century, 39 Stetson L. ReV. 861, 895-99 (2010).

105. Id. at 898-99.

106. Id. at 899.

107. 10 U.S.C. $\S \S 251-255$.

108. $I d$.

109. Id. § 251.

110. Id. $\$ \$ 252-253$.

111. Id. § 254 .

112. The emergency powers doctrine also allows the president to deploy federal forces domestically. See Dougherty, supra note 16, at 17-22.

113. See Vladeck, supra note 3, at 164.

114. Id. at 168.

115. Id. at 169. 
the Supreme Court, at least in part, is to blame for the continued expansion of the president's already broad authority under the Act. By failing to adequately define the sources and extent of the president's emergency domestic military power, the Court has left the door open to continued and unnecessary expansion of the president's discretion. Congress, seemingly for the sake of expediency, has removed nearly all the checks on presidential power under the Act. Part III argues that the reduced checks on presidential power have not resulted in a more effective Insurrection Act. By analyzing select instances when the Insurrection Act was invoked, Part III attempts to show that increased checks on presidential power would not have resulted in significantly different outcomes in these instances.

\section{Use in Modern Times}

The Insurrection Act is rarely invoked. ${ }^{116}$ The most recent instance was in 1992 in Los Angeles. ${ }^{117}$ The Act's modern usage primarily revolves around racial tensions, including violence and discriminatory applications of the law. ${ }^{118}$ This Part will describe select instances of the Act's use and provide commentary regarding the outcomes and how the same could be achieved with greater checks on the president's power under the Act.

\section{A. Little Rock, Arkansas, 1957}

On May 17, 1954, the Supreme Court handed down its landmark ruling in Brown v. Board of Education of Topeka. ${ }^{119}$ The Court concluded "in the field of public education the doctrine of 'separate but equal' has no place." ${ }^{120}$ As a result, the arduous and occasionally violent desegregation of schools began around the nation. ${ }^{121}$ In 1955, the Court issued a supplementary opinion to their 1954 ruling in Brown to compel the states lagging behind in their desegregation efforts to implement racially nondiscriminatory school admission policies "with all deliberate speed." 122 The Court recognized the unique difficulties that individual schools confronted while they made the transition, so the

116. Libby Cathey, What Is the Insurrection Act and Why Has It Been Invoked Before?, ABC (June 2, 2020, 4:20 PM), https://abcnews.go.com/Politics/insurrectionact-invoked/story?id=71020988 [https://perma.cc/G9R2-5CUD].

117. See Anjuli Sastry et al., When LA Erupted in Anger: A Look Back at the Rodney King Riots, NPR (Apr. 26, 2017, 1:21 PM), https://www.npr.org/2017/04/26/ 524744989/when-la-erupted-in-anger-a-look-back-at-the-rodney-king-riots [https:// perma.cc/S6R3-3NCS].

118. Cathey, supra note 116.

119. Brown v. Bd. of Educ., 347 U.S. 483 (1954), supplemented, 349 U.S. 294 (1955).

120. Id. at 495.

121. Alexis Clark, Why Eisenhower Sent the 101st Airborne to Little Rock After Brown v. Board, Hist. (Apr. 8, 2020), https://www.history.com/news/little-rock-ninebrown-v-board-eisenhower-101-airborne [https://perma.cc/JE37GA9U].

122. Brown, 349 U.S. at 301. 
Court ordered that each institution "make a prompt and reasonable start toward full compliance," resting the burden upon each defendant to show the time stipulated to desegregate was necessary and granting the local courts authority to determine whether these efforts were in good faith. ${ }^{123}$

Three days after the original 1954 ruling, the Little Rock District School Board ("School Board") issued a public statement stating, "It is our responsibility to comply with Federal Constitutional Requirements[,] and we intend to do so when the Supreme Court of the United States outlines the method to be followed." 124 Meanwhile, Arkansas state representatives were actively working against desegregation of their schools by promulgating racist state laws intended to perpetuate the current system of racial discrimination. ${ }^{125}$ The School Board was undeterred and went forward with the first stage of their desegregation program, which desegregated grades ten through twelve for senior high schools. ${ }^{126}$ In the midst of infighting between Arkansas lawmakers and its educational institutions, nine Black students, who would become known as the "Little Rock Nine," ${ }^{27}$ were enrolled in Central High School in 1957. ${ }^{128}$ On September 2, 1957, one day prior to the Nine's first day at Central High School, and without a request by the school, the Governor of Arkansas deployed the Arkansas National Guard and made the school "off limits" to Black students. ${ }^{129}$ This action catalyzed several responses, including an investigation by the U.S. Attorney for the Eastern District of Arkansas initiated on September 4, 1957. ${ }^{130}$ Eventually, after a federal district court enjoined the Governor from using the National Guard to obstruct or interfere with the school's policy, the Nine were able to enter the high school on September 23, 1957, with assistance from the Little Rock Police Department. ${ }^{131}$

However, while the Governor yielded to the district court's order, the injunction did not prevent a large crowd of demonstrators gathered outside the school from causing the Nine to be removed from campus the same morning. ${ }^{132}$ Simultaneously, President Eisenhower signed Executive Order No. 10730, invoking his power to send federal army troops to Central High School to enforce federal law where willful obstruction "ma[de] it impracticable to enforce such laws by the

123. Id. at 300.

124. Cooper v. Aaron, 358 U.S. 1, 7 (1958).

125. Id. at $8-9$.

126. $I d$.

127. Little Rock Nine, Hist., https://www.history.com/topics/black-history/centralhigh-school-integration (Jan. 19, 2021) [https://perma.cc/9XBC-R5YA].

128. Cooper, 358 U.S. at 9.

129. Id.

130. $I d$. at 11 .

131. Id. at $11-12$.

132. Id. at 12 . 
ordinary course of judicial proceedings." 133 The federal troops arrived on September 25, 1957, and remained until November 27, 1957, when they were replaced by a federalized National Guard unit, which remained until the end of the school year. ${ }^{134}$

Several aspects of the Arkansas case warrant discussion and additional consideration. First, racial tension is a dominant factor underlying this modern invocation of the Insurrection Act. ${ }^{135}$ Second, despite being an example of troop deployment occurring against the will of the state and its governor, this instance seems to be a perfect example of why the Act is necessary and how domestic deployment of federal troops by the president can be desirable. Third, President Eisenhower acted under what is now $\S 252$ of the Act, which granted him unilateral discretion to send federal troops (this is one of the sections this Comment argues Congress should amend).

President Eisenhower's invocation of $\S 252$ is particularly relevant to the argument that unilateral discretion is necessary to promote expediency. But consider that twenty-two days passed after the Governor of Arkansas used the National Guard to prevent the Nine from entering the building and President Eisenhower invoking the Act; one more day passed before the troops arrived for a total of twenty-three days between the action causing obstruction and the troop deployment correcting it. Notably, Executive Order No. 10730, signed on September 24, 1957, included the proclamation to disperse as required, but only one day was allowed to pass prior to troop arrival on September $25 . .^{136}$

Arguably, only the last two days are relevant because, presumably, Eisenhower waited until it was clear that Arkansas could not handle the situation on its own before he intervened. However, it stands to reason that if there were an expedited judicial or congressional review process that would substantiate the president's determination, which he could unilaterally initiate when a crisis arose, the same outcome could have been realized here so long as the process took less than twenty-one days.

\section{B. Alabama 1963 and the Stand in the Schoolhouse Door}

On two occasions in 1963, President John F. Kennedy federalized and deployed National Guard troops. ${ }^{137}$ First, he sent troops to the University of Alabama on June 10 and then second to Tuskegee High

133. Exec. Order No. 10,730, 22 Fed. Reg. 7628 (Sept. 24, 1957).

134. Cooper, 358 U.S. at 12.

135. Cathey, supra note 116.

136. Exec. Order No. 10,730, 22 Fed. Reg. 7628 (Sept. 24, 1957).

137. University of Alabama Desegregated, Hist., https://www.history.com/this-dayin-history/university-of-alabama-desegregated (June 12, 2020) [https://perma.cc/ TQ2F-9ASW]. 
School in September. ${ }^{138}$ Similar to Eisenhower in Little Rock, Kennedy signed Executive Order No. 11111 to enforce school desegregation policies. ${ }^{139}$ During what is popularly known as the "Stand in the Schoolhouse Door," ${ }^{140}$ controversial Alabama Governor George Wallace literally stood in the doorway of the University of Alabama, accompanied by state troopers, to prevent two Black students from desegregating the school. ${ }^{141}$ Wallace only yielded after Kennedy's federalized National Guard confronted him. ${ }^{142}$ A few months later, in September, Wallace once again tried to block the integration of another school, Tuskegee High School. ${ }^{143}$ Once again, he only yielded to Kennedy's troops once he was confronted with overwhelming federal pressure. ${ }^{144}$

Kennedy was likely not surprised by the Stand in the Schoolhouse Door incident. In fact, Wallace campaigned on a segregationist platform and made it clear that he would stand in the door to prevent Black students from entering and integrating the University of Alabama. ${ }^{145}$ As early as April 25, 1963, Robert Kennedy and Assistant Attorney General Burke Marshall began meeting with Wallace to negotiate the integration of the University of Alabama. ${ }^{146}$ Wallace asked for the meeting to be taped so that he could show Alabamians the federal government was willing to send federal troops to enforce the law. ${ }^{147}$ These negotiations took place months before the infamous event and included discussions about the procedure to be followed if Wallace did in fact stand in the doorway. ${ }^{148}$

The Stand in the Schoolhouse Door shows that not all crises develop overnight; they can arise after months of negotiations and national publicity, which should provide ample time to prepare in advance, as Kennedy actually did in this instance. Although not all crises will build up over a period of months, the ones that do build up

138. Id.

139. Exec. Order No. 11,111, 28 Fed. Reg. 5709 (June 11, 1963).

140. Debra Bell, George Wallace Stood in a Doorway at the University of Alabama 50 Years Ago Today, U.S. News (June 11, 2013, 2:05 PM), https://www.usnews.com/ news/blogs/press-past/2013/06/11/george-wallace-stood-in-a-doorway-at-the-universi ty-of-alabama-50-years-ago-today [https://perma.cc/RAE9-B7TN].

141. University of Alabama Desegregated, supra note 137.

142. Id.

143. $I d$.

144. $I d$.

145. Whose Law?: State Sovereignty and the Integration of the University of Alabama, John F. Kennedy Presidential Libr. \& Museum, https:// www.jfklibrary.org/learn/education/teachers/curricular-resources/high-school-curricular-resources/whose-law-state-sovereignty-and-the-integration-of-the-university-of-alabama [https://perma.cc/R8ZN-DZ2Y].

146. Id.

147. Id.

148. The Stand in the Schoolhouse Door, ENCYCLOPEDIA.COM, https:// www.encyclopedia.com/politics/legal-and-political-magazines/stand-schoolhouse-door (Feb. 19, 2021) [https://perma.cc/9FB8-XYST]. 
slowly provide ample time for the president to submit the possibility of federal military involvement to an independent review process. Granted, this is another example of the Act being invoked and used responsibly for the advancement of civil rights. However, it is also an instance where, prior to invocation, the president had time to consider the political and legal ramifications of the move. Certainly, in similar cases, the need for an ultra-expedient review is mitigated by the circumstances themselves. If this proposition is true, then what harm would come from the president submitting his determination for review that certain actions, if taken, would warrant deployment of federal troops? This infamous example supports the argument that if the president was forced to seek a judgment from an independent review, it would not hinder the Act's usefulness due to a lack of expediency.

\section{Rodney King Riots 1992}

In Los Angeles, California, 1991, after a high-speed chase, Los Angeles police officers ordered Rodney King out of his vehicle and kicked and beat him with batons for fifteen minutes. ${ }^{149}$ A video of the incident showed more than a dozen police officers standing by and watching the beating. ${ }^{150}$ The incident resulted in four officers being charged with excessive use of force. ${ }^{151}$ However, one year later, on April 29, 1992, a jury acquitted all four officers. ${ }^{152}$ Within hours, the community responded with chaos and violence that lasted for five days and resulted in more than 50 riot-related deaths, over 2,000 injuries, and almost 6,000 arrests. ${ }^{153}$

Quickly, it became clear that the Los Angeles Police Department, with assistance from the California National Guard, could not handle the wide-spread violence and riots on its own. ${ }^{154}$ Pete Wilson, the governor of California at the time, requested that President George H.W. Bush send federal troops to assist in restoring order to the city under what is now $\S 251$ of the Insurrection Act. ${ }^{155}$ Shortly after, President Bush deployed 4,000 federal troops to the city, and within days the riots became manageable. ${ }^{156}$

149. Sastry et al., supra note 117.

150. Id.

151. $I d$.

152. $I d$.

153. Id.

154. See id.

155. Mark Nevitt, The President and the Domestic Deployment of the Military: Answers to Five Key Questions, Just SEC., https://www.justsecurity.org/70482/the-president-the-military-and-minneapolis-what-you-need-to-know/ (June 2, 2020) [https:// perma.cc/9FBE-BG32].

156. Paul Taylor \& Carlos Sanchez, Bush Orders Troops into Los Angeles, WAsH. Post (May 2, 1992), https://www.washingtonpost.com/archive/politics/1992/05/02/ bush-orders-troops-into-los-angeles/4c4711a6-f18c-41ed-b796-6a8a50d6120d/ [https:// perma.cc/VBV4-WZPB]. 
This situation is unique among the selected uses of the Insurrection Act because while racial tensions do underlie the cause of violence, the deployment of troops was meant to address the violence itself, not the underlying cause. The Rodney King riots are significant because of the speed with which the intensity of the violence escalated (within hours of the nonguilty verdict) and the method used to deploy federal troops. Thousands of injuries and dozens of deaths occurred within mere days. Truly, this is an instance where expediency was of the highest value. Fortunately, both the California Governor and the President agreed on that. Even more fortunate is that the Insurrection Act provided an avenue for the president to respond quickly to a state's request for assistance. Where a crisis is so urgent and the possible damage so significant that it requires the rapid deployment of federal troops to address it, state representatives should reasonably be trusted to identify the crisis as such. Here, concerns about the president abusing powers granted by the Act are greatly diminished because the unilateral determination that federal troops are necessary is nonexistent. Therefore, the amendments argued for in this Comment are not applicable to this situation because sufficient checks, in the form of bilateral agreements between federal and state governments, are already in place. Aside from the violence and injury, this instance represents the ideal balance of power between the federal government and the states. The bilateral agreement standard could also be applied to the other sections of the Insurrection Act that allow the president to unilaterally deploy troops against a state's will. Instead of an agreement between federal and state governments, the agreement would be between the executive branch and either the legislative or the judicial branch.

\section{AmEnding InsurRection}

This Part identifes the sections in the Insurrection Act that should be amended to restore adequate checks on the president's power under the Act. Next, it presents recently proposed amendments to the Act and critiques them from the position that an effective amendment tends to restore the original checks. Following that analysis, this Comment provides an explanation of the relationship between the Posse Comitatus Act ("PCA") and the Insurrection Act, primarily because some scholars argue that domestic presidential military power can be checked by amending the PCA while others claim this is not possible and the PCA is largely misunderstood. ${ }^{157}$

\section{A. The Language at Issue}

Sections 252 and 253 of the Insurrection Act should be amended to require additional checks and a method for obtaining independent ap-

157. See Dougherty, supra note 16 , at 3. 
proval for the mobilization of armed forces within the United States. The power to use federal troops within a state, against the state's will, should not be conditioned upon the discretion of a single individual. Any proposed amendments should leave the president's power to request the use of federal troops and to retain or delegate command of those troops, once approval is received, intact. I include the language of both sections to be amended, beginning with $\S 252$ :

Whenever the President considers that unlawful obstructions, combinations, or assemblages, or rebellion against the authority of the United States, make it impracticable to enforce the laws of the United States in any State by the ordinary course of judicial proceedings, he may call into Federal service such of the militia of any State, and use such of the armed forces, as he considers necessary to enforce those laws or to suppress the rebellion. ${ }^{158}$

The differences between $\S 252$ and $\S 253$ are the situations that permit the use of the statute. Section 253 states as follows:

The President, by using the militia or the armed forces, or both, or by any other means, shall take such measures as he considers necessary to suppress, in a State, any insurrection, domestic violence, unlawful combination, or conspiracy, if it-

(1) so hinders the execution of the laws of that State, and of the United States within the State, that any part or class of its people is deprived of a right, privilege, immunity, or protection named in the Constitution and secured by law, and the constituted authorities of that State are unable, fail, or refuse to protect that right, privilege, or immunity, or to give that protection; or

(2) opposes or obstructs the execution of the laws of the United States or impedes the course of justice under those laws.

In any situation covered by clause (1), the State shall be considered to have denied the equal protection of the laws secured by the Constitution. ${ }^{159}$

With the specific language identified, this Comment now moves on to recently proposed amendments.

\section{B. Recently Proposed Amendments}

On July 20, 2020, the Democratically controlled House passed H.R. 7135, which contained amendments to the Insurrection Act as part of the National Defense Authorization Act. ${ }^{160}$ The amendments would require a certification to Congress for $\S 251, \S 252$, and $\S 253$ prior to

158. 10 U.S.C. $\S 252$.

159. Id. § 253.

160. Rebecca Kheel, House Votes to Curtail Insurrection Act Powers, The HiLl, https://thehill.com/policy/defense/508197-house-votes-to-curtail-insurrection-act-powers?rl=1 (July 20, 2020, 8:53 PM) [https://perma.cc/3UNJ-PT78]. 
troops being deployed. ${ }^{161}$ For $\S 251$, which allows a state to request assistance, the president along with the secretary of defense and the attorney general ("certifying group") would need to certify to Congress that the state has requested the aid described to suppress an insurrection. ${ }^{162}$ For $\S 252$, which is invoked for unlawful obstruction, the certifying group must certify that the "State concerned is unable or unwilling to suppress an unlawful obstruction." 163 The certifying group must also include a description of the circumstances, demonstrable evidence that the state is unable or unwilling to suppress an unlawful obstruction, and a description of the scope of the invocation. ${ }^{164}$ Finally, for $\S 253$, the requirements are the same as $\S 252$ except that now the certifying group must certify that the "State concerned is unable or unwilling to suppress an insurrection."165

Additionally, the proposed amendments would create $\S 256, \S 257$, $\S 258$, and $\S 275 .{ }^{166}$ Section 256 would require that "the President, in every possible instance ... consult with Congress before invoking the authority under $[\S \S] 251,252$, or $253 .{ }^{\prime \prime 67}$ Proposed $\S 257$ would impose a fourteen-day limit on any approved invocation of the Act and provide for expedited extension procedures. ${ }^{168}$ Section 258 would establish a judicial review for injuries sustained by individuals as a result of the Act's invocation as well as for challenging the invocation itself. ${ }^{169}$ Lastly, $§ 275$ would restrict federally deployed military personnel from conducting "a search, seizure, arrest, or other similar activity unless participation in such activity by such member is otherwise expressly authorized by law." 170

Opponents of the bill have argued the amendment "would dangerously constrain troops and delay a president's ability to respond to a riot." ${ }^{171}$ In part, I agree. It is unnecessary to certify requests from a state especially in instances like the Rodney King riots where the federal and state governments were in agreement. But the Act is not only used to quell riots. Recall that President Kennedy invoked the Act to desegregate schools where the need for expediency was not as significant. I will expound on these arguments after the introduction of other proposed amendments that have either not passed, been stalled, or failed in the House.

161. H.R. 7135, 116th Cong. $\S \S 2,3,4$ (2020).

162. Id. $\S 2$.

163. Id. $\S 3$.

164. Id.

165. Id. § 4.

166. Id. $\S \S 5-8$.

167. Id. \$ 5 .

168. Id. \$ 6 .

169. Id. \$ 7.

170. Id. $\S 8$.

171. Kheel, supra note 160. 
H.R. 7215, which is currently stalled, proposes that congressional notification, distinct from certification, should be required for $\S 251$, $\S 252$, and $\S 253$ and that a fourteen-day termination limit should apply to invocations of the Act. ${ }^{172}$ Under the notification requirement, the president must submit to the appropriate members of Congress "notice of the intent to exercise such authority together with the justification of the President for exercising such authority."173

H.R. 7124, otherwise known as the LIMIT Act, is worth mentioning because unlike any of the proposed amendments covered thus far, this bill sought to allow use of $\S 251, \S 252$, and $\S 253$ only after the president had declared a national emergency. ${ }^{174}$ Additionally, H.R. 7129 proposed that except in cases of natural disaster, the president is granted only three days to exercise the authority granted by the Act. ${ }^{175}$

There are two other propositions worth mentioning that have been reported in news articles and are not included in any proposed legislation at this time. First, Congress could forbid invocation of the Act in response to peaceful assembly. ${ }^{176}$ Alternatively, Congress could impose stricter "triggering criteria" presumably by specifically enumerating the circumstances that would warrant the use of federal troops. ${ }^{177}$

\section{Obtaining Approval and Other Checks}

For ease and clarity purposes, I consider the proposed amendments collectively, specifically focusing on the process required for independent approval, time limits for presidential action, and additional checks, respectively.

\section{Process for Obtaining Independent Certification}

The original 1792 Militia Act required the president obtain judicial certification from a federal judge prior to invoking the Act. ${ }^{178}$ The modern Insurrection Act lacks any such certification requirement. ${ }^{179}$ An independent certification or approval requirement is necessary, at least for $\S 252$ and $\S 253$, because these sections contain the unilateral language that distorts the original conception of the balance of domes-

172. H.R. 7215, 116th Cong. $\$ 2$ (2020).

173. $I d$.

174. H.R. 7124, 116th Cong. \& 2 (2020).

175. H.R. 7129, 116th Cong. § 2 (2020).

176. Kelly Magsamen, 4 Ways Congress Can Amend the Insurrection Act, CTR. FOR AM. Progress (June 12, 2020, 4:00 AM), https://www.americanprogress.org/issues/ security/news/2020/06/12/486261/4-ways-congress-can-amend-insurrection-act/ [https:// perma.cc/3L4D-WLZ4].

177. Kimberly Wehle, 4 Ways to Prevent a Future Insurrection, Atlantic (Jan. 13, 2021), https://www.theatlantic.com/ideas/archive/2021/01/how-remove-danger-periodamerican-law/617651/ [https://perma.cc/KP7B-HN3X].

178. Vladeck, supra note 3 , at 159-60.

179. 10 U.S.C. $\$ \S 252-53$. 
tic military power. To better preserve this original conception, some form of bilateral agreement between multiple offices or branches of government that a situation warrants the use of federal troops is necessary.

H.R. 7135, the bill that passed in the House, remedies this by requiring that a certifying group submit certification to Congress for $\S 251, \S 252$, and $\S 253$, but it goes too far. Only $\S 252$ and $\S 253$ suffer from the unilateral language that creates an imbalance of power. When a president acts pursuant to $\S 251$, it is guaranteed that the state itself has "certified" the existence of a crisis and desires federal troops. The president could also simply refuse if they disagree, but either way, both parties would ultimately answer to their constituents. Under $\S 251$, the state itself is arguably the most important "certifier" and the only one that is reasonably necessary. Otherwise, the Act stands to sacrifice expediency, and by extension usefulness, for the sake of double certification. Congressional certification for $\S 251$ is not a desirable improvement and would not restore the balance of power the Framers intended.

In contrast, H.R. 7215, which would impose a congressional notification of intent requirement, falls short of restoring the balance of power. Primarily, this is because notifying Congress about the intention to use the Act does not amount to a bilateral agreement between independent offices or branches. It must be conceded that a notification requirement would be an improvement to the status quo, but the requirement would add little protection against abuses and create another obstacle to expediency for next to nothing in return. Presumably, after receiving the president's notification of intent, Congress would be able to act quickly to stop them if they saw fit. But what legal mechanism would be used to overcome the unilateral authority the president has under an express congressional delegation, especially when the Supreme Court has held the president's determination is largely unreviewable? The notification requirement ignores the unilateral language of the Act and, as a likely result, the amendment does not require congressional acquiescence.

For the sake of argument, assume the Rodney King riots represent an obvious example of when domestic deployment of federal troops is beneficial and necessary. It is one extreme of the spectrum that is characterized by debilitating riots, chaos, and an insufficient response from local law enforcement due to operational capabilities. At this extreme, reasonable state representatives will identify the situation as requiring federal assistance if their own response is inadequate, which historically, they have had time to determine. On the other extreme of the spectrum is the desegregation of Central High School in Little Rock, Arkansas, where over a period of months the state legislature and its governor, in defiance of the Supreme Court, not only attempted to enact laws to perpetuate segregation but actually used its 
National Guard to prevent the execution of federal law. In other words, the federal and state governments disagreed vehemently about whether federal troops should be deployed. Further, assume for both instances that deploying federal troops was the "right" decision and produced the most desirable outcome.

Within the hypothetical framework, the Act appears to work reasonably well. The instance that truly required expediency (the Rodney King riots) was quickly completed with a bilateral agreement, and the less expeditious instance (desegregating Central High School in Little Rock) was carefully considered over several months. In Little Rock, although President Kennedy did not seek congressional certification, the negotiations and planning during the months-long lead-up to the invocation likely achieved some of the same benefits certification would. The real difficulty arises from ambiguous cases that do not fall into either extreme. In these cases, where only one party believes federal troops are necessary and what is "right" is not clear, the current Insurrection Act is only concerned about one opinion-the president's. This imbalance of power is what necessitates a bilateral agreement between independent parties. Of course, it is possible more complicated cases will arise where a state is under siege but refuses to ask for help. The existence of a bilateral agreement becomes even more desirable in these cases. Even if the agreement is between Congress and the president and not the state itself, it still prevents unilateral determinations from being used to domestically deploy troops, which is perhaps one of the most controversial actions a president can take.

\section{Time Limits for Presidential Action}

The only time limits imposed on the president in the 1792 Militia Act provided the president with thirty days after the commencement of the next session of Congress to continue a troop deployment if Congress was not in session and the president used the militia of another state within one of the surrounding states. ${ }^{180}$ H.R. 7135 provides fourteen days for all invocations of the Act and expedited extension procedures if necessary. ${ }^{181}$ This appears to be a reasonable compromise. Although some invocations require extended troop deployment, as in Little Rock where they stayed for an entire school year, the fourteen-day requirement forces the president to regularly consider whether troops are necessary. Ideally, this will lead to shorter deployments, but if not, there are expedited extension procedures.

On the other hand, the LIMIT Act only provides the president with three days unless it is during a natural disaster. ${ }^{182}$ Three days is likely

180. Vladeck, supra note 3 , at 160.

181. H.R. 7135, 116th Cong. \& 6 (2020).

182. Limit Act, H.R. 7124, 116th Cong. $§ 2$ (2020). 
administratively unworkable. The amount of "red tape" involved may help deter unnecessary deployments but is likely to cause more frustration than relief in situations where the deployment is clearly necessary. However, without more information about what is required each time the termination period expires, it is difficult to argue that one limit is preferrable to the other. Currently, § 252 and $\S 253$ are not limited by any amount of time, so any time limit appears preferable to no time limit. But based on the selected instances above, fourteen days seems to be the most workable logistically.

\section{Additional Checks}

The additional checks and restrictions proposed for the Act do not have historical equivalents. Judicial review, restrictions for searches and seizures, and natural disaster provisions will be considered respectively. Judicial review for individual injuries and invocation of the Act itself is not found in any of the preceding amendments to the Act. Arguably, it can still be maintained that the Framers would prefer more checks than less, so long as they do not impede the Act's usefulness. Judicial review would not play a part in the approval process, but it may impact expediency if the president is fighting injunctions from quickly filed lawsuits. Potential liability for injury would operate as a check that would likely manifest itself in the training of the troops deployed; however, if it is unrestricted, it could lead to costly and time-consuming litigation. Given that the Supreme Court has held the president's determination to be largely unreviewable by courts, an amendment granting judicial review would very likely need to blaze a completely new legal trail.

Preventing deployed troops from participating in searches, seizures, and other similar activities may provide a workable compromise; however, many troops are trained similar to local law enforcement on these procedures. Perhaps by limiting troops who do not have that training from participating, the amendment would not hamper the usefulness of the Act. However, part of the purpose in deploying federalized troops is to assist local law enforcement in performing the tasks they normally perform but which they are unable to do because of a crisis. With additional qualifications, such as requiring troops to abide by local policies, the amendment might encourage the use of local troops as opposed to federal troops, which is likely desirable to the local population.

Restricting the Act to use only during natural disasters destroys the usefulness of the Act and ignores the basic premise for having it in the first place; crises arise that require military involvement to be quelled, and they are certainly not limited to natural disasters. Under this formulation of the Act, President Eisenhower could not have desegregated Central High School, nor could President Kennedy have desegregated the University of Alabama. 
In summary, an amendment to the Insurrection Act should work toward restoring the original balance of power envisioned by the Framers. To meet this challenge, lawmakers should focus on including a certifying group for $\S 252$ and $\S 253$ and imposing a termination time limit. They should be wary that overregulation, such as the imposition of additional requirements on $\S 251$, should be avoided because it will hinder the usefulness of the Act.

\section{Restoring the Balance}

Based on the analysis above, the language of $\S 252$ should be amended to the following (alterations in italics):

Whenever the President, following certification to Congress by the certifying group, considers that unlawful obstructions, combinations, or assemblages, or rebellion against the authority of the United States, make it impracticable to enforce the laws of the United States in any State by the ordinary course of judicial proceedings, he may call into Federal service such of the militia of any State, and use such of the armed forces, as he considers necessary to enforce those laws or to suppress the rebellion.

The "certifying group" will consist of the president, the secretary of defense, and the attorney general. Additionally, one more provision is necessary. A fourteen-day time limit should be imposed for all invocations of the Act, with expedited extension procedures. The proposed amendment borrows the "certifying group" and the time limit from H.R. 7135.

Similarly, the relevant language of $\S 253$ should be amended to the following (alterations in italics):

The President, following certification to Congress by the certifying group, by using the militia or the armed forces, or both, or by any other means, shall take such measures as he considers necessary to suppress, in a State, any insurrection, domestic violence, unlawful combination, or conspiracy, if it-

A fourteen-day time limit provision will also be included. Once again, the "certifying group" and time limit requirement is borrowed from H.R. 7135. The desirability of other proposed amendments, such as forbidding military action against peaceful protesters, should be acknowledged. But this Comment does not advocate for their inclusion because their inclusion reduces the likelihood that Congress would adopt this amendment. The proposed amendment represents a practical compromise between the balance of power and the necessary expediency when responding to an insurrection. Importantly, § 251 will not be altered by this proposed amendment. It should be noted here that amending the Insurrection Act is only one way to rein in the power of the president. The discussion of the Posse Comitatus Act that follows describes another possible pathway, or lack thereof, to reining in the president's domestic military power. 


\section{E. The Posse Comitatus Act}

The PCA was enacted in 1878 to function as a criminal statute. ${ }^{183}$ Its enactment represented the codification of the American ideological value that the military should not be used to enforce civilian law. ${ }^{184}$ The PCA punishes conduct that, without constitutional or congressional authorization, "willfully uses any part of the Army or the Air Force as a posse comitatus or otherwise to execute the laws." 185 The Latin term "posse comitatus" is defined in Black's Law Dictionary as "power of the county." ${ }^{186}$ Essentially, the PCA was designed to prevent the use of federal troops to enforce the law by citizens lacking the authority to do so, which amounts to almost all citizens with few exceptions. ${ }^{187}$

This Comment largely avoids the contemporary debate about whether the PCA is necessary or even relevant to curtailing executive power. However, it is important to understand the basic foundations of why this Comment considers it irrelevant. The PCA begins by stating it applies to anyone with the exception of individuals and "circumstances expressly authorized by the Constitution or Act of Congress." 188 The Insurrection Act is an act of Congress explicitly delegating the power to the president to use federal troops to enforce the law under certain circumstances. ${ }^{189}$ The statute specifically excludes congressional authorizations from its application and the Insurrection Act is such an authorization. ${ }^{190}$ Logically, the PCA has no bearing on the president when he invoke the Insurrection Act and use federal troops to enforce the law.

This formulation of the relationship between the Insurrection Act and the PCA raises the following question: After invoking the Insurrection Act and deploying federal troops to enforce the law, can the president ever act in a way that would amount to a violation of the PCA? In other words, what are the congressional limitations placed on the president by the PCA when using federal troops as authorized by Congress in the Insurrection Act? Applying the reasoning of the argument above, the answers to those questions are "no" and "none," respectively.

Interestingly, commentators argue the PCA was only intended "to prohibit civilian marshals from calling forth active duty military to en-

183. Nathan Canestaro, Homeland Defense: Another Nail in the Coffin for Posse Comitatus, 12 Wash. U. J.L. \& PoL'y 99, 99 (2003).

184. Id.

185. 18 U.S.C. $\S 1385$.

186. Posse Comitatus, Black's Law Dictionary (11th ed. 2019).

187. Dougherty, supra note 16, at 3; see Eric V. Larson \& John E. Peters, Preparing the U.S. Army fOr Homeland Security 243-45 (2001).

188. 18 U.S.C. $\S 1385$.

189. 10 U.S.C. $\$ \S 251-53$.

190. 18 U.S.C. $\$ 1385$. 
force domestic law." ${ }^{191}$ Congress, however, allows the president to invoke $\S 252$ and $\S 253$ of the Insurrection Act and deploy federal troops unilaterally. ${ }^{192}$ The comparison highlights that despite the codification of the American value that the military should not be used by individuals to enforce domestic law, Congress delegated the power to do just that to a single individual, conditioned on their sole discretion.

\section{CONClusion}

The domestic deployment of federal troops will continue to be controversial. Consistently, Congress has moved away from the original conception the Framers had about the balance of domestic military power. By reducing the checks on presidential authority, Congress opens the door to potential abuses. Based on the historical uses of the Insurrection Act, it is almost certainly necessary, and its use has repeatedly expanded and enforced the protection of civil rights. Although creating a certifying group is a start, in the future lawmakers should begin incorporating additional amendments that rely on bilateral agreements between independent offices and branches of the government, which would allow Congress to ensure the Act's continued vitality and usefulness while also maintaining the proper balance of power. The emergence of proposed legislation for the rarely used Act suggests it is time for Congress to consider the Act's future and the potential dangers it poses. Considering that the Act, at least in modern times, has been used primarily to address racial tensions, Congress should look to draw parallels between the past and today's tumultuous racial relations when deciding appropriate amendments.

191. Dougherty, supra note 16, at 3.

192. 10 U.S.C. $\$ \S 252-53$. 